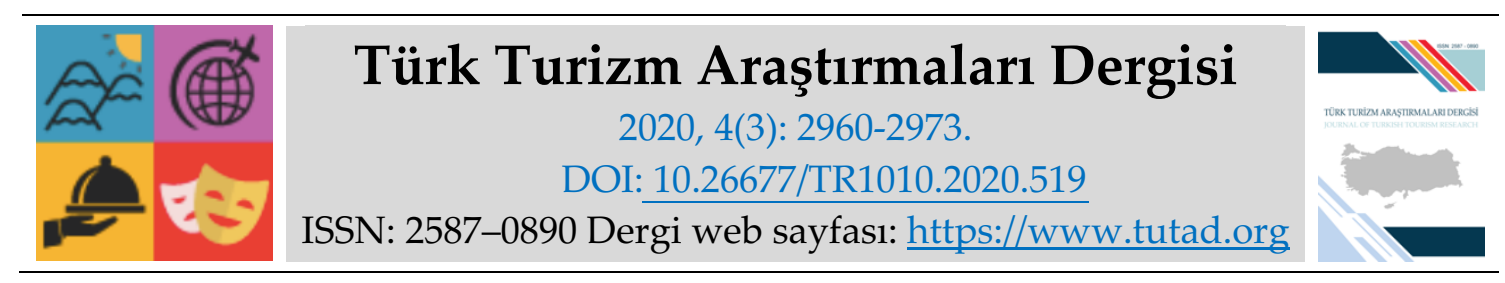

ARASTIRMA MAKALESI

\title{
Şirince'de Faaliyette Bulunan Yiyecek ve İçecek İşletmelerinin Tripadvisor Yorumlarının İçerik Analizi
}

Dr. Öğr. Üyesi Ahu YAZICI AYYILDIZ, Adnan Menderes Üniversitesi, Turizm Fakültesi, Aydın, e-posta: ayazici@adu.edu.tr

ORCID: https://orcid.org/0000-0002-1301-2428

Öz

Teknolojinin gelişmesiyle birlikte turizm sektöründe ve onun altında yer alan yiyecek ve içecek sektöründe tüketiciler satın alma kararı vermeden önce internet ortamında bilgi toplamaktadırlar. Çevrimiçi yorum sitelerinde yer alan tüketicilerin olumlu ve olumsuz yorumları karar verme ve satın alma davranışlarını etkilemektedir. Bu çalışmanın amacı Şirince'de faaliyette bulunan restoranlara ilişkin Tripadvisor'da yer alan olumsuz müşteri yorumlarını belirlemektir. Restoran işletmeleri için yapılan olumsuz yorumlar yemek, personel, fiyat, servis, atmosfer ve temizlik kriterlerine göre değerlendirilerek, içerik analizine tabi tutulmuştur. Restoran müşterilerinin en çok olumsuz yorum yaptığı kriterlerin yemek, servis ve fiyat olduğu ortaya çıkmıştır. Bu kriterlerin altında yer alan şikayetlerin yemeğin kötü ve lezzetsiz olması, soğuk servis edilmesi, servisin yavaş olması ve fiyatın pahalı olması nedeniyle ortaya çıktığı belirlenmiştir. Çalışma olumsuzlukların giderilmesi için restoran yöneticilerine öneriler ve ileride yapılabilecek çalışmalarla ilgili alternatiflerle sonlandırılmıştır.

Anahtar Kelimeler: Yiyecek ve İçecek İşletmeleri, Müşteri Şikayetleri, Şirince.

Makale Gönderme Tarihi: 26.05.2020

Makale Kabul Tarihi: 04.07.2020

\section{Önerilen Atıf:}

Yazıcı Ayyıldız, A. (2020). Şirince'de Faaliyette Bulunan Yiyecek ve İçecek İşletmelerinin Tripadvisor Yorumlarının İçerik Analizi, Türk Turizm Araştırmaları Dergisi, 4(3): 2960-2973.

(C) 2020 Türk Turizm Araştırmaları Dergisi. 


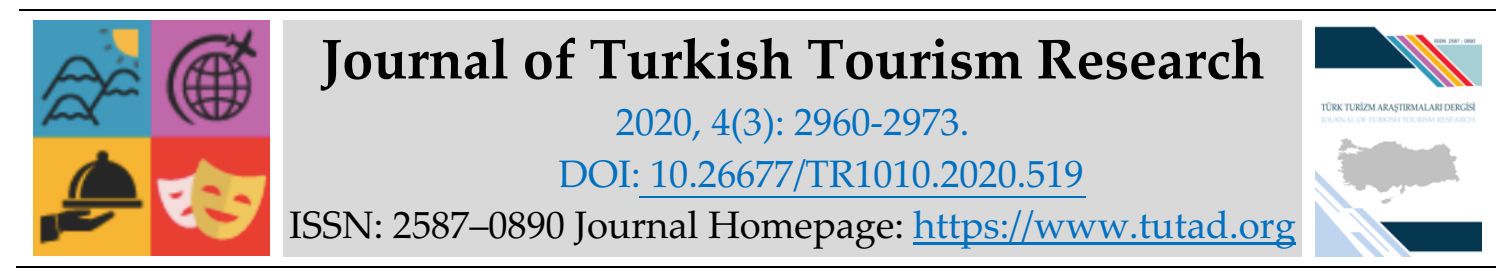

\title{
$\underline{\text { RESEARCH PAPER }}$
}

\section{Content Analysis of Tripadvisor Reviews of Food and Beverage Companies Operating in Şirince}

Assistant Prof. Dr. Ahu YAZICI AYYILDIZ, Adnan Menderes University, Faculty of Tourism, Aydın, e-mail: ayazici@adu.edu.tr

ORCID: https://orcid.org/0000-0002-1301-2428

\begin{abstract}
With the development of technology, consumers gather information in the internet environment before making a purchase decision in the tourism sector and the food and beverage sector under it. The positive and negative comments of consumers on the online review sites affect the decision making and buying behavior. The purpose of this study is to determine the negative customer comments on Tripadvisor regarding the restaurants operating in Şirince. Negative comments made for restaurant businesses were evaluated according to the criteria of food, staff, price, service, atmosphere and cleanliness and subjected to content analysis. It has been revealed that the criteria that restaurant customers make most negative comments are food, service and price. It has been determined that the complaints under these criteria arise due to bad and unpleasant food, cold service, slow service and expensive price. The study was ended with suggestions for restaurant managers and alternatives for future work to eliminate the problems.
\end{abstract}

Keywords: Food and Beverage Business, Customer Complaints, Şirince.

Received: 26.05 .2020

Accepted: 04.07.2020

\section{Suggested Citation:}

Yazıcı Ayyıldız, A. (2020). Content Analysis of Tripadvisor Reviews of Food and Beverage Companies Operating in Şirince, Journal of Turkish Tourism Research, 4(3): 2960-2973.

(c) 2020 Türk Turizm Araştırmaları Dergisi. 


\section{Gíriş}

Günümüzde tüketiciler fizyolojik ihtiyaçların karşılanmasının ötesinde, sosyal ihtiyaçların karşılanması (Hjalager ve Richards, 2002), keyifli bir yemek deneyimi yaşamak (Johns ve Kivela 2001) ve yenilik arayışlarını karşılayacak alternatiflerin peşinde koştukları için (Ha ve Jang, 2013: 155) restoranları ziyaret etmektedirler. Yemek yenecek restoran seçiminde yemek kalitesi, yemeğin fiyatı, yemek çeşitliliği, yemek yenen yerin atmosferi ve uygunluğu gibi kriterler tüketiciler tarafından dikkate alınmaktadır (Lewis, 1981). Tüm sektörlerde olduğu gibi yiyecek ve içecek sektöründe de müşteri memnuniyeti sağlamak, sadık müşteri yaratmak işletmelerin temel hedefleri arasındadır.

İletişim teknolojilerinin gelişmesi yiyecek ve içecek sektöründe de birtakım yenilikleri ve gelişmeleri beraberinde getirmiştir. Günümüz tüketicisi restoran tercihi yapmadan önce internette araştırma yaparak hizmet alma eğilimindedir. Özellikle sosyal medya ve Tripadvisor gibi web sayfaları tüketicilerin tercihlerinde önemli bir yere sahiptir. Tüketicilerin satın alma kararını olumlu ya da olumsuz etkilemesi açısından bu sayfalarda yapılan yorumlar oldukça önemlidir (Tiago, Amaral ve Tiago, 2015:164). İnternet ortamında yapılan tüketici yorumları ürünler veya hizmetlerle ilgili bilgiler sunması ve olası müşteriler için olumlu veya olumsuz referanslar sağlaması açısından önemlidir (Durmaz ve Yüksel, 2017: 231). İnternette yapılan tüketici yorumları, ürünler veya hizmetlerle ilgili değerlendirmeleri tüketici bakış açısıyla ortaya koyduğundan, yorumları okuyan diğer tüketicilerin satın alma davranışları üzerinde oldukça etkilidir. Ayrıca tüketiciler, herhangi bir ürün, hizmet veya markayla ilgili yorum yapan tüketicilerin, ürünü, hizmeti veya markayı herhangi bir çıkar gözetmeksizin önerdiklerini düşündüğünden, bu yorumlara daha fazla itimat etmekte ve bu yorumları daha ikna edici olarak görmektedirler (Cengiz ve Başaran, 2016: 76).

Tüketicinin almış olduğu hizmetten memnun kalmaması ve beklentilerinin karşılanmaması durumunda müşteri şikâyeti ortaya çıkmaktadır. Memnun olmayan tüketici yaşadığı sorunu işletme personeline aktarma, işletmeye tekrardan gitmeme veya çevresindekilere işletmeyi kötüleme ve onlara o işletmeye gitmeme tavsiyesinde bulunma gibi davranışlar sergilemektedir (Özaslan, Uygur, 2014:71). Müşteri şikayetlerinin çözümü; müşteri memnuniyetinin sağlanması ve müşteri bağlılığının oluşturulması açısından, ayrıca müşterilerin kulaktan kulağa yayacağı olumsuz haberleri azaltması açısından oldukça önemlidir (Unur vd., 2010). İşletmeler, müşterilerine kaliteli hizmet vermek için müşterilerini dinlemeli ve şikayetlerini dikkate almalıdır. Bu sayede rekabet avantajı da elde ederler (Kitapçı, 2008).

Bu çalışmada Şirince'de faaliyet gösteren restoran işletmelerine yönelik TripAdvisor web sitesindeki şikayet konularıyla ilgili yapılan yorumlara içerik analizi uygulanmıştır. Ortaya çıkan sonuçlara göre de işletmelere yönelik öneriler getirilmiştir.

\section{Yiyecek ve İçecek İşletmeleriyle İlgili Literatür Taraması}

Yapılan literatür taraması sonucunda restoran deneyimleri ile ilgili yapılan çalışmalarda genel olarak restoran boyutunun yemek, hizmet kalitesi, atmosfer, hijyen, fiyat, lokasyon gibi faktörlerden oluştuğu görülmektedir. Bu çalışmada da yemek, personel, fiyat, servis, atmosfer, temizlik boyutları ele alınmıştır. Bu konuyla ilgili literatürde yapılan daha önceki çalışmalar aşağıda belirtilmiştir.

Soriano (2002), İspanya'da müşterilerin tekrar yemek için bir restorana dönme kararlarını etkileyen özellikleri araştırmıştır. Araştırma sonucunda yemek kalitesi en önemli özellik olarak ortaya çıkarken, ikinci sırada servis kalitesi, üçüncü sırada yemeğin fiyatı ve değeri, son sırada ise restoranın ambians ve lokasyonu önemli özellikler olarak ortaya çıkmıştır. 
Namkung, Jang (2008), Amerika'da orta ve üst seviyede yer alan dört restoranda oldukça memnun olan ve olmayan restoran müşterilerini ayıran restoran özelliklerini ortaya koymayı amaçlamıştır. Çalışmada yemeğin sunumu ve lezzeti, mekanın atmosferi, servis kalitesi, müşterilerin yüksek memnuniyetine katkıda bulunan önemli özellikler olarak belirtilmiştir.

Liu ve Jang (2009), çalışmalarında ABD'de bulunan Çin restoranlarının değerlendirmiş, atmosferle ilgili özelliklerin en çok şikâyet edilen konu olduğu, sonra sırasıyla müzik, aydınlatma, iç mekân tasarımı ve dekor un şikayet konusu olduğu ortaya çıkmıştır.

Pantelidis (2010), Londra'da faaliyet gösteren 300 restoranla ilgili 2.471 müşteri yorumunu değerlendirmiş, müşterilerin gıda, hizmet, ambiyans, fiyat, menü ve dekoru (bu sırayla) dikkate aldıkları vurgualnmıştır.

Ha, Jang (2010), çalışmalarında etnik restoranlarda müşteri memnuniyeti ve sadakatini sağlayan unsurların yemek ve hizmet kalitesi olduğunu ortaya koymuşlardır.

Zhang, Law, Li (2010), kişisel deneyimlere dayalı tüketici tarafından üretilen incelemeler ve profesyonel editörler tarafından yazılan incelemelerin çevrimiçi kullanıcı davranışı üzerindeki etkileri araştırılmış, restoranların gıda, hizmet ve çevre kalitesinin tüketicilerin odaklandığı başlıklar olduğu ortaya çıkmıştır.

Jeong, Chang (2011), çalışmalarında hangi restoran deneyimlerinin müşterileri olumlu elektronik ağızdan ağıza (E-Wom) yönlendirmeye teşvik ettiğini araştırmış, restoranların gıda kalitesinin, müşterilerin olumlu E-Wom yaymalarını olumlu yönde etkilediğini, servis çalışanlarıyla tatmin edici restoran deneyimlerinin olumlu E-Wom'u tetiklediği ortaya çıkmıştır. Restoranlarda fiyat adaletİ ise, restoran müşterilerini E-Wom'a yöneltmemiştir.

Albayrak (2013), İstanbul ilinde birinci sınıf restoranlarda yaptığı çalışmada, müşterilerin en fazla çalışanlar ile ilgili sorunlar yaşadıkları ayrıca yiyecek-içeceklerin lezzeti, menü kartında olan yiyeceklerin sunulamaması, restoranın iklimlendirme sistemi ve çalışanların ilgisizliği olduğunu belirtmiştir.

Petzer ve Mackay (2014), çalışmalarında Güney Afrika'da 250 restoranda müşteri memnuniyetinin belirleyicilerini araştırmış, müşteri memnuniyeti belirleyicilerinin yemek ve hizmet kalitesi olduğu ortaya çıkmıştır.

Özaslan ve Uygur (2014), çalışmalarında Yalova şehrinde faaliyet gösteren yiyecek içecek işletmelerinde araştırma yapmış, restoranlarla ilgili servisin yetersiz ve yavaş olması, fiyatın yüksek olması ve lavaboların yetersiz ve temiz olmaması konularında şikâyetler olduğu belirtilmiştir.

Lei, Law (2015), Macau bölgesindeki restoranlarla ilgili Tripadvisor sitesindeki tüketici değerlendirmeleri hizmet, yemek, fiyat, atmosfer boyutlarıyla incelenmiştir.

Doğan, Yücel, Tanrısevdi (2016), Kuşadası'nda faaliyet gösteren ve TripAdvisor Mükemmellik Sertifikası'na sahip yiyecek ve içecek işletmeleriyle ile ilgili yazılan olumsuz yorumları değerlendirmiş, yemek, çalışan personelin tutumu ve fiyat kriterlerin yiyecek ve içecek işletmelerinin değerlendirilmesinde önem taşıdığı görülmüştür.

Kim, Li, Brymer (2016), TripAdvisor sitesinde mükemmellik sertifikasına sahip restoranlarla ilgili sosyal medyada yer alan yorumların, işletmelerin finansal performansını nasıl etkilediğini araştırmış, yemek, hizmet kalitesi, fiyat, atmosfer boyutları ele alınmıştır.

Dalgıç, Güler, Birdir (2016), çalı̧̧malarında Hatay ve Mersin şehirlerinde faaliyet gösteren yöresel lezzet sunan restoranlara ilişkin şikayetleri araştırmış, yiyecek boyutu içerisindeki lezzettin en 
fazla şikâyet unsuru olduğu, atmosferle ilgili özelliklerin şikâyet olarak son sırada geldiği sonucuna varılmıştır.

Erdem, Yay (2017), Antalya il merkezindeki birinci sınıf restoranlara ilişkin olumsuz yorumları incelemiş, restoran müşterilerinin sırasıyla personel, daha sonra yiyecek içecek, servis, fiyat, hizmet ortamı ve menüyle ilgili şikâyet ettiği bulunmuştur.

Şahin vd. (2018), Alaçatı'da faaliyet gösteren restoranlara yönelik e-şikâyetleri incelemiş, Alaçatı'da faaliyet gösteren restoranları deneyimleyen müşterilerin en fazla fiyatlandırmadan kaynaklanan sorunlara yönelik şikâyetlerde bulunduğu saptamıştır. Ayrıca, sipariş edilen yemekten farklı yemek kokularının gelmesi ve restoran mobilyalarının ergonomik olmaması gibi şikâyetlerin sıkça tekrar edildiği görülmüştür.

Li, Meng, Jeong, Zhang (2020), çalışmalarında restoranlarda yapılan müşteri değerlendirmelerinin daha sonra yapılacak değerlendirmeleri etkileyip etkilemediğini araştırmış ve restoranlarda ki ortalama değerlendirme notunun aynı restoran için sonraki inceleme derecelendirmeleri üzerinde olumlu bir etkiye sahip olduğu ortaya çımıştır.

Özbay, Sarıca (2020), Sakarya Serdivan'da faaliyet gösteren zincir restoran ilişkin sikayetvar.com sitesinde paylaşılan müşteri şikayetlerinin nedenleri ortaya koymak amacıyla yaptıkları çalışmada, müşterilerin en çok hizmet kalitesi, ürün sunumu ve hijyen konusunda şikayet ettikleri ortaya çıkmıştır.

Yapılan çalışmalar incelendiğinde müşteri memnuniyetinin sağlanmasının restoran işletmelerinde önemli olduğu, memnuniyeti sağlanmış müşterilerin olumlu elektronik ağızdan ağıza iletişime (E-Wom) yöneldiği, memnuniyeti sağlanmayan müşterilerin ise olumsuz elektronik ağızdan ağıza iletişime (E-Wom) yöneldiği ortaya çıkmıştır. Özellikle Türkiye'de yapılan çalışmalarda Tripadvisor web sayfasının deneyimlerini paylaşmak isteyen tüketiciler tarafından yoğun olarak kullanıldığı anlaşılmıştır. Restoran deneyimleri ile ilgili yapılan çalışmalarda yemeğin sunumu ve lezzeti, hizmet kalitesi, atmosfer, fiyat, personelin tutumu, hijyen gibi kriterlerin öne çıktığı belirlenmiştir.

\section{E-WOM ve Müşteri Şikayetleri}

Tüketiciler satın alma kararını verirken, diğer insanların (arkadaş, aile, tanıdık vb.) kararlarına güvenerek önerilerini, tekliflerini ve kişisel tavsiyelerini dinleyerek karar verirler (Kalpaklığlu ve Toros, 2011, s. 4113) Yaşadıkları olumlu ve olumsuz deneyimleri de başkalarına aktarırlar. Yaşadıkları olumlu deneyimleri başkalarına tavsiye ederek, olumsuz deneyimleri ise kötüleme tarzında, şikayet niteliğinde aktarırlar (Anderson, 1998). Tüketiciler tatil kararı vermeden önce de konaklayacakları oteller, ulaşım imkanları, yemek yiyecekleri restoranlar hakkında bilgi toplarlar. Bu bilgi kaynaklarının içerisinde arkadaşlar, internet, seyahat acentaları çok büyük bir paya sahiptir (Doğan, Yücel ve Tanrısevdi, 2016).

En eski yöntemlerden pazarlama yöntemlerinden biri olan ağızdan ağıza iletişim (word of mouth-Wom) günümüze dek önemini yitirmeden ulaşmıştır. Ağızdan ağıza iletişim ile ilgili çalışmalardan ilki 1967 yılında Arndt tarafından yapılmıştır. Arndt Wom'u; ticari bir amaç gütmeden bir ürün, marka ya da hizmet hakkında alıcı ve kaynak arasında gerçekleşen sözlü bir iletişim olarak tanımlamıştır (Arndt, 1967). Anderson'a göre ise, ağızdan ağıza iletişim, bireyler arasında ürün ve hizmetlerin değerlendirilmesiyle ilgili resmi olmayan iletişim şeklidir (Anderson, 1998). Ağızdan ağıza iletişim işletmenin satışlarının artması ve marka imajının güçlenmesi için kişilerin birbirleri ile olan ilişkilerini kullanan bir pazarlama yöntemidir. 
İnternet kullanımının yaygınlaşması ile birlikte bireyler arasında gerçekleşen iletişim de geleneksel iletişim yöntemlerinden farklılaşarak dijital platformlarda taşınmıştır (Moqadamsalimi, 2019). Geleneksel yöntemlerle karşılaştırıldığında internet, bilgi aktarmanın çok daha ucuz ve hızlı bir yoludur (Lee, Park ve Han, 2008). Bu da daha çok tercih edilmesini sağlamaktadır. Her geçen gün daha fazla sayıda tüketici bilgi edinmek için internet tabanlı tartışma forumlarını, blogları, tüketici yorum sitelerini ve sosyal ağları kullanmaktadır (Cheung ve Thadani, 2010:329). Elektronik ağızdan ağıza iletişim internet üzerinden tüketiciler arasında kişilerarası bir ilişkidir (Lee, Noh ve Kim, 2013). Elektronik ağızdan ağıza iletişim de (E- Wom), ağızdan ağıza iletişim (Wom) gibi tüketici tarafından veya üretici/ satıcı tarafından oluşturulmaktadır (Sijoria, Mukherjee ve Datta, 2018). Bu tür bir iletişim, müşterilerin mal ve hizmetlerin performansının her aşamasını izleyebilmesini sağlamıştır ve bu nedenle günümüzde E-Wom alışveriş dünyasında Wom dan daha popüler olmuştur (Moqadamsalimi, 2019). Ayrıca elektronik ağızdan ağıza iletişimin daha önce görülmemiş bir iletişim hızına sahip olması, daha etkili, daha ulaşılabilir olması ve daha ölçülebilir olması nedenleriyle geleneksel ağızdan ağıza iletişimden daha etkin olduğunu vurgulanmaktadır (Cheung ve Lee, 2012).

Günümüzde tüketiciler satın aldıkları ürün veya hizmetten memnun kalmadıklarında, ürün ve hizmetle ilgili şikâyette bulunarak, negatif yönlü E-Wom yoluyla olumsuz düşüncelerini ve deneyimlerini arkadaş çevrelerine anlatarak işletmeleri cezalandırdıklarını düşünürler. (Özaslan ve Uygur, 2014: 74). Aslında şikayet eden müşteri işletmenin eksiklerini göstererek, işletmenin kendisini olumlu yönde geliştirmesine destek olmaktadır. İşletmelerin aldıkları şikayetleri doğru yönetebilmesi, müşteri memnuniyetini sağlaması kadar önemlidir (Lee vd., 2003, Buhalis vd., 2008, Albayrak 2013). Şikayette bulunan müşteriler, şikayetlerine çözüm bulunduğu takdirde sorunu olan ama şikayette bulunmayıp sessiz kalan müşterilere oranla aynı işletmeye daha fazla gelme eğilimdedirler (Lewis 1983: 25). Bu noktada işletmelerin müşterilerini elde tutabilmeleri için müşteri şikayetlerine ve şikayetlerin çözümlerine gereken önemi vermesi gerekmektedir. Müşteriler şikayetlerinin sonrasında gerçekleştirilen çözümle ilgili tatmin olmamış ise, tatmin olmuş müşterilere oranla iki kat daha fazla negatif ağızdan ağıza iletişim yapmaktadırlar (Goodman ve Newman, 2003: 55).

Anlaşılacağı üzere müşteri şikâyetleri işletmeler için aslında bir fırsattır. İşletmelerin şikayetlere olumsuz gözle bakmaması ve şikayetleri kendilerini geliştirecekleri, eksiklerini görecekleri bir ortam olarak değerlendirmeleri gerekmektedir. Müşteri şikayetleri çözümlendiğinde işletme ile ilgili olumlu bir imaj yaratılarak, memnu olan müşterinin sadık müşteri haline gelmesi de sağlanacaktır.

\section{Araştırmanın Amacı ve Önemi}

Bu çalışmanın amacı, Şirince'de faaliyette bulunan yiyecek ve içecek işletmeleri hakkındaki olumsuz görüşleri belirleyerek, bu doğrultuda işletmelere yönelik öneriler geliştirmektir.

Şirince destinasyonunda yiyecek ve içecek işletmelerinin müşteri şikayetlerinin değerlendirilmesi ile ilgili literatürde daha önce çalışmaya rastlanmamış olması konunun önemini ortaya koymaktadır.

\section{Araştırmanın Kapsam ve Sınırlılıkları}

Çalışmanın kapsamını www.tripadvisor.com web sitesinde yer alan Şirince destinasyonunda faaliyette bulunan yiyecek işletmeleri için yazılan olumsuz yorumlar oluşturmaktadır. Araştırmanın sınırlılıkları ise, Tripadvisor'da yiyecek ve içecek işletmelerine ait yapılan 
yorumlardan sadece 3 (ortalama), 2 (zayıf) ve 1 (berbat) puan alanların kullanılması ve TripAdvisor sitesinin dinamik bir yapıya sahip olması ve her an yeni bir yorumun eklenmesi durumunun olmasından dolayı 31.05.2020 tarihine kadar yapılan yorumların dikkate alınmış olmasıdır.

\section{Araştırmanın Evren ve Örneklemi}

Araştırmanın evrenini www.tripadvisor.com web sitesinde Şirince'de faaliyet gösteren toplam 351 yiyecek ve içecek işletmesi için yazılan yorumlar oluşturmuştur. Araştırma örneklemini ise, www.tripadvisor.com web sayfasında yer alan Şirince'de faaliyet gösteren toplam 34 işletmeden, olumsuz müşteri yorumları içeren toplam 23 yiyecek ve içecek işletmesi oluşturmaktadır. Her dilde olumsuz yorum yapan kullanıcılar araştırma kapsamına alınmıştır. Çeviri programları yardımıyla yorumlar Türkçe'ye çevrilmiş ve analiz edilmiştir. Yiyecek ve içecek işletmelerinden 1=berbat, 2=kötü, $3=$ ortalama puan alan yorumlar araştırmada veri olarak kullanılmıştır.

\section{Veri Toplama Yöntemi}

Çalışmanın verileri Tripadvisor web sitesinde yer alan çevrimiçi tüketici yorumları kullanılarak toplanmıştır. Verilerin elde edildiği yorumlar 2010 yılı Ocak ayından 2020 yılı Haziran ayına kadar ki dönem arasından seçilmiştir. Veriler 1-31 Mayıs 2020 tarihleri arasında toplanarak analiz edilmişlerdir. Araştırmada, veri toplama aracı olarak doküman analizi yönteminden yararlanılmıştır. Tripadvisor, ziyaretçilerine restoranlar, oteller, destinasyonlar, havayolu işletmeleri, gemi seyahatleri gibi birçok konuda bilgi veren ve internet sitesindeki bilgilerin diğer kullanıcılarla paylaşılmasına olanak sağlayan bir seyahat sitesidir. Tripadvisor, 49 farklı ülkede ve 28 dilde hizmet vermektedir. (Tripadvisor, 2019). Tripadvisor dünyanın en büyük çevrimiçi seyahat topluluğu ve kullanıcılar tarafından oluşturulan içeriklerin incelendiği en popüler web sitelerinden biridir (O'Connor, 2008).

\section{Veri Analiz Yöntemi}

$\mathrm{Bu}$ çalışmada nitel araştırma yöntemlerinden içerik analizi kullanılmıştır. TripAdvisor sitesindeki 351 yorum üzerinden analizler gerçekleştirilmiştir. Bu kapsamda öncelikle, veriler derlenmiş ardından derlenen veriler sayısallaştırılmış ve benzer yorumlar gruplandırılarak değerlendirilmiştir. Yorumlar farklı dillerde gerçekleştirildiğinden verilerin derlenmesi sürecinde yabancı dilde yapılan yorumlar Türkçeye çevrilerek analiz edilmiştir. Çalışmada verilerin gruplandırılmasında Doğan, Yücel ve Tanrısevdi (2016) çalışmasında kullanılan restoran kriterlerinden yararlanılmıştır. Bu kriterler yemek, personel, fiyat, servis, atmosfer ve temizliktir.

Şirince'de faaliyet gösteren TripAdvisor'daki yiyecek içecek işletmeleriyle ilgili ortalama (3), zayıf (2) ve berbat (1) değerlendirmesi yapan kullanıcıların yorumları 6 farklı kriter altında değerlendirilmiştir. Bu kriterler; yemek, personel, fiyat, servis, atmosfer ve temizliktir.

Yapılan içerik analizi sonucunda toplam 351 yorum belirlenmiştir. Yorumların kriterlere göre dağılımına bakıldığında yemek kriteri birinci sırada yer alırken (f:183), ikinci sırada servis (f:113), üçüncü sırada fiyat (f:96) yer almaktadır. Söz konusu kriterleri personel (f:80), temizlik (f:29) ve atmosfer (f:11) takip etmektedir. 
Tablo 2. Yorum Yapan Kullanıcıların Demografik Özellikleri

\begin{tabular}{|l|l|}
\hline $\begin{array}{l}\text { Yorum Yapan Kullanıcıların } \\
\text { Cinsiyetleri }\end{array}$ & Yorum Yapan Kullanıcıların Milliyetleri \\
\hline Kadın: 105 & $\begin{array}{l}\text { Türk: Hindistan: 1 Almanya:7 Belçika: 2 İtalya:4 } \\
\text { Brezilya:3 İngiltere:13 Ukrayna:1 Cezayir:1 Hollanda:1 } \\
\text { Azerbaycan:1 Kanada:2 Avustralya: 6 Abd: 18 Kibris:1 } \\
\text { Birleşik Arap Emirlikleri: 1 Norveç: 1 Kuveyt:1 } \\
\text { Yunanistan:2 } \\
\text { Singapur:1 Mexica:1 İsviçre:1 Fransa:1 Luxemburg: } 1 \\
\text { Katar:1 İspanya:1 Yeni Zelanda:1 Slovenya:2 İrlanda:1 } \\
\text { Polonya:1 }\end{array}$ \\
\hline Erkek: 132 & Yabancı Yorum Sayısı: 99 \\
\hline Cinsiyeti Belirlenemeyen: 114 & Yerli Yorum Sayısı:251 \\
\hline Toplam: 351 & Toplam:351 \\
\hline
\end{tabular}

Yapılan yorumlarla ilgili Tablo 3'de belirtilen kriterlere ait değerlendirmelerden dikkat çeken örnekler aşağıda verilmiştir. Yemek ile ilgili "çok kötü" olarak ifade edilen yorumlarda "yenecek gibi değil", "hamur kızartmaları yanmış ve kurumuş halde masaya getirildi", "bugüne kadar yediğimiz en kötü kabak çiçeği dolması idi, kurumuş ve kuruduğu anlaşılmasın diye 1sıtıllmış ama durum daha kötü olmuş", "omlete kullandıkları yağ ile 2 akşam yemeği pişirirsiniz", "kötü" olarak ifade edilen yorumlarda, "et yemekleri başarılı değildi, kötüydü", "menemen kötü, pişi pişmemişti", "yemekler kötü, çökertme istedik, eti tuza batırmışlar sanki", "et yağlıydı, tadı da kötüydü", "soğuk geldi" olarak nitelendirilen yorumlarda, "yemekler soğuk geldi, kavurma söyledik, kavurmanın bile soğuk gelmesi çok şaşırtıcıydı, masada tealightla 1sındı", "çay soğuk geldi", "pide istedik buz gibi geldi", "ana yemek soğuktu", "mantı buz gibi geldi", "çöp şiş söyledim kısa sürede geldi ama soğuktu ısıtılmamış ekmekle yemeğe çalıştım", "lezzetsiz" olarak ifade edilen yorumlarda, "güveçte kuru fasulye hiç lezzetli değildi", "şişler çok lezzetsizdi", "yemekler yavan ve tatsız", "verdiğiniz ücrete değmeyecek tadı lezzeti olmayan bir yemek", et sotenin lezzeti beklediğimden çok daha kötüydü, "kabak çiçeği dolmasının içi kıtır kıtır ve lezzetsiz", "yorumlara istinaden geldik eşim mantı yedi ben tavuk şiş, ikisi de lezzetsizdi", "porsiyonlar çok küçük" olarak nitelendirilen yorumlarda, "mezelerin porsiyonları çok azdı", ". köftenin boyutları gerçekten küçük, bu işletmede yemek yiyen aç kalır", "Ege bölgesi ile ilgisi olmayan bir meze gelişi güzel çok minik porsiyonla sunuldu", "mantı, sarma , şevketi bostan hepsi de lezzetliydi, ama sarmanın porsiyonu ufacı̆̆ın ufacığı geldi, mantının porsiyonu fena değildi ama onun da yoğurdu çok çok azdı", "berbat" olarak ifade edilen yorumlarda, "et yenecek gibi değildi, tadı berbattı", "yemekler, mezeler çok berbat", "ot kavurma berbat, çöp şiş rezalet", "ailecek gittiğimiz mekanda sac kavurma istedik, eşim ve oğlum zehirlendi", "tarhana çorbası diye getirdikleri domates çorbası, üstelik adeta salça çorbası, ot kavurma berbat" ifadeleri dikkat çekmiştir.

Yiyecek içecek işletmelerinde yapılan servisi "çok yavaş" olarak nitelendiren ifadelerde "verdiğimiz sipariş için 25 dakika bekletildik ve siparişiniz neydi diye sordular işletme sahipleri o kadar amatör ki özür dileyip müşteriyi tutacakları yerde ağız dalaşına giriyorlar", 
“inanmıyorum resmen 20 dakika menü bekledim 30 dakika sipariş vermeyi bekledim, siparişimi almamışlar bile sipariş verseydim oda 90 dakikaya gelirdi herhalde kalktım gittim", "yemek servisi 25 dakika sürdü, restoranın yarısı boştu", "servis yavaş, sipariş verip, servis alıp, hesabı ödeyinceye kadar baya bekledik", "kötü" olarak ifade edilen yorumlarda, "siparişimiz yanlış geldi", "bir lokantada servis ne kadar kötü olabilir burada tecrübe edebilirsiniz, yemekler lezzetli ancak servisteki inanılmaz aksaklıklar bizi çileden çıkardı", "bu kadar güzel bir bina, Şirince'yi yukardan gören çok güzel bir lokasyon ancak servis kötü" ifadeleri öne çıkmıştır.

Tablo 3. Yorumlarda En Sık Kullanılan Kelimelerin Frekansları

\begin{tabular}{|c|c|c|c|c|c|}
\hline Yemek & Servis & Fiyat & Personel & Temizlik & Atmosfer \\
\hline $\begin{array}{l}\text { Çok kötü } \\
\text { n:22 }\end{array}$ & $\begin{array}{l}\text { Yavaş } \\
\text { n:52 }\end{array}$ & $\begin{array}{l}\text { Çok } \\
\text { pahalı } \\
\text { n:11 } \\
\end{array}$ & $\begin{array}{l}\text { İlgisiz } \\
\text { n:23 }\end{array}$ & $\begin{array}{l}\text { Çok kötü } \\
\text { n:25 }\end{array}$ & $\begin{array}{l}\text { Gürültülü } \\
\mathrm{n}: 2\end{array}$ \\
\hline $\begin{array}{l}\text { Kötü } \\
\text { n:35 }\end{array}$ & $\begin{array}{l}\text { Kötü } \\
\text { n:45 }\end{array}$ & $\begin{array}{l}\text { Pahalı } \\
\text { n:78 }\end{array}$ & $\begin{array}{l}\text { Kaba } \\
\text { n: } 25\end{array}$ & $\begin{array}{l}\text { Kötü } \\
\text { n:1 }\end{array}$ & $\begin{array}{l}\text { Çok Kalabalık } \\
\text { n:3 }\end{array}$ \\
\hline $\begin{array}{l}\text { Siradan } \\
\text { n:12 }\end{array}$ & $\begin{array}{l}\text { Çok } \\
\text { yavaş } \\
\text { n:11 } \\
\end{array}$ & $\begin{array}{l}\text { Değmez } \\
\text { n:7 }\end{array}$ & $\begin{array}{l}\text { Suratsiz } \\
\text { n:19 }\end{array}$ & $\begin{array}{l}\text { Berbat } \\
\mathbf{n}: 3\end{array}$ & $\begin{array}{l}\text { Arı çok } \\
\mathrm{n}: 2\end{array}$ \\
\hline $\begin{array}{l}\text { Soğuk geldi } \\
\text { n:19 }\end{array}$ & $\begin{array}{l}\text { Berbat } \\
\text { n:5 }\end{array}$ & & $\begin{array}{l}\text { Sayg1s1z } \\
\text { n:8 }\end{array}$ & & $\begin{array}{ll}\text { Kedi, } & \text { köpek } \\
\text { çok } & \\
\text { n:2 } & \\
\end{array}$ \\
\hline $\begin{array}{l}\text { Lezzetsiz } \\
\mathbf{n}: 28\end{array}$ & & & $\begin{array}{l}\text { Amatör } \\
\text { n:5 }\end{array}$ & & $\begin{array}{l}\text { Soğuk } \\
\text { n:2 }\end{array}$ \\
\hline $\begin{array}{l}\text { Porsiyonlar } \\
\text { küçük } \\
\text { n:18 }\end{array}$ & & & & & \\
\hline $\begin{array}{l}\text { İyi değil } \\
\text { n:15 }\end{array}$ & & & & & \\
\hline $\begin{array}{l}\text { Berbat } \\
\mathbf{n}: 20\end{array}$ & & & & & \\
\hline $\begin{array}{l}\text { Vasat } \\
\text { n:11 }\end{array}$ & & & & & \\
\hline $\begin{array}{l}\text { Ortalama } \\
\mathrm{n}: 3\end{array}$ & & & & & \\
\hline
\end{tabular}

Fiyat kriterinde "çok pahalı" ifadesi kullanılan yorumlarda "fiyatlar her ürün grubu için çok yüksek", "fiyatlar oldukça faiş, ayıptır ya insanı enayi yerine koymayın", "lezzete göre fiyat çok yüksekti, "şarap fiyatları çok yüksekti”, "fiyatları İzmir, Çeşme fiyatı", " 2 kişi 1 çorba bir de siniye $110 \mathrm{tl}$ hesap geldi bu paraya ve içinde et bile yok bence çok yüksek, bir de şarap alalım dedik, 3 şişe aldık sonra gezince nasıl bir kazık yediğimizi fark ettik yazık", "porsiyonlar küçük,fiyatlar çok büyük", "fiyatlar çok fazla, steak house da bile daha ucuza yersin t bone steak yersin, Şirince'nin her yerinde satılan 70 cc lik meyve şarabı 25 TL her yerde, orada 70 TL, sonuçta köy burası Şirince ismini kullanıp bu derece fais fiyat yapmak bence buranın adını bir süre sonra lekeler", "Şirince' de gördüğümüz en yüksek fiyatlar buradaydı", "değmez" olarak nitelendirilen ifadelerde "asla bu hizmete ve fiyata gitmeye değmez", "yöresel yiyecekler için bu fiyata değmez" ifadeleri dikkat çekmiştir. 
Yiyecek ve içecek işletmelerinde çalışan personeli "kaba" olarak nitelendiren yorumlarda "sipariş almak için gelen amca kalkın gidin der gibi davrandı, biz de kalktık gittik", "garsonları kaba , menüyü önünüze atan bir yer", "suratsız" olarak nitelendirilen ifadelerde "ben bu kadar somurtkan, itici servis personeline çok az rastladım", "kahvaltı yapmaya gittik suratlar bir karış nerden çıktınız der gibi hizmet veriyorlar", "içeri girince niye geldin gibi bir suratla karşılaşınca yemek yiyeceğimi beyan etmek zorunda kaldım", "ilgisiz" olarak ifade edilen yorumlarda "tek zorumuza giden ise mekandan ayrılırken hiç kimsenin sizi uğurlamaması (halbuki bahşişimizi de bırakmıştık ), ne bir "teşekkürler" ne de bir "tekrar bekleriz", öylece mekandan çıkıyorsunuz", "manzaranın mükemmelliğine kapılmayınız çalışanları misafirlerle ilgilenmeye niyetleri yok", "çalışanlar bu güzel köye yakışır şekilde değil, ilgi yok", "müşteri olarak gelmiş olmamız çalışanları hiç memnun etmedi, çok soğuk davranışlar sergilediler, tavsiye etmiyoruz", "saygısız" olarak nitelendirilen ifadelerde, "servis yapan arkadaş fonda çalan şarkıya sesli bir şekilde eşlik ediyor nedeni anlamadım, sigarasını içip geliyor elleri, nefesi, üstü başı leş gibi sigara kokuyor. Bir çay istiyorsun masa 36 ya çay yaz diye başımda bağırıyor. Bir uçtaki servis elemanı diğer uçtaki arkadaşına buraya sen mi bakıyorsun diye bağırıyor", "garsonları ukala karşıma oturmak isteyen yeğenim için masayı çekmeyip yanınıza otursun dediler beyefendi oraya oturmak istiyor dediğimizde bu kelimeye takılıp sürekli beyefendi ne içer beyefendi ne yer beyefendi çok acıkmış deyip ukalalık ettiler, su istettik kola getirdiler, birde ben içerim tamam kolayı deyip ukalalık ettiler" ifadeleri dikkat çeken ifadelerdir.

Temizlik ile ilgili yapılan değerlendirmelerde "çok kötü" ifadesini nitelendiren yorumlarda "servis edilen tabaklar, çatallar ve özellikle tuvalet hiç temiz değildi, "menüler çok kirliydi", "mutfak kısmına göz gezdirdim, hijyen kurallarına dikkat edildiği pek söylenemez, peynirin üstünde minik sineklerden vardı", "kahvaltı masasına gelen çay bardakları inanılmaz pisti, görerek getirmeleri beni şaşırttı", "hijyen olarak çok iyi değil, masa örtüleri kirliydi", "tuvaletler çok pisti", "temizlik açısından oldukça problemli. Tabaklar, bardaklar vs leke içindeydi", "eşime gelen su bardağı kirliymiş, su içmemiş bana da söylememiş çıtıktan sonra söyledi. Masayı biz söylemeden silmediler toz içindeydi" öne çıkan değerlendirmelerdir.

Atmosfer kriterinde "gürültülü" olarak yapılan değerlendirmelerde "çok gürültülü bir yerde, tam Şirince'nin girişinde ve yol üstünde, gelen geçen arabaların kornası gürültüsü eşliğinde yemek yedik", "ortam olarak maalesef gürültülü bir yer, köyün girişinde ve sıklıkla çalan kornalardan, sürücü tartışmalarından rahatsız olduk", "arı çok" olarak yapılan değerlendirmede "arılardan rahat edemedik, çocuklar çok rahatsız oldu", "kesinlikle tavsiye etmiyorum, arı istilasından yemek yiyebilirseniz ne ala", "soğuk" olarak yapılan değerlendirmelerde "buz gibi elektrikle ısıtma yapılmaya çalışılmış ama izolasyon kötü olduğu için içerisi soğuk", "kedi, köpek çok" ile ilgili değerlendirmede, "masaların üzerinde kediler dolaşıyor, hayvan sevmeme rağmen çok rahatsız oldum", "kedi, köpek masa etrafında çok fazlaydı, çok rahatsız olduk" ifadeleri dikkat çekenler arasındadır.

\section{SONUÇ ve ÖNERILER}

Günümüzde her sektörde olduğu gibi yiyecek ve içecek sektöründe de artan rekabetten dolayı müşteri memnuniyetini ve sadakatini sağlamak çok önemli hale gelmiştir. Müşteri memnuniyetini ve sadakatini sağlayan faktörler çok çeşitli olmakla birlikte restoran işletmelerinde restoranın atmosferi, müşterilerine sunduğu hizmetin kalitesi, restoranda çalışan personelin müşterilere karşı tutum ve davranışları, restoranın hijyeni, ürünlerin fiyatlandırılması en önemli faktörler olarak ortaya çıkmıştır.

Bu çalışmada Şirince'de faaliyet gösteren yiyecek ve içecek işletmeleriyle ilgili Tripadvisor web sitesinde yapılan yorumlardan 3 (ortalama), 2 (zayıf) ve 1 (berbat) 2 (zayıf) ve 1 (berbat) puan 
alan değerlendirmeler incelenmiştir. Değerlendirme kriterleri yemek, servis, fiyat, personel, temizlik ve atmosferdir. Yorumların kriterlere göre dağılımına bakıldığında yemek kriteri (f:183) birinci sırada yer almaktadır. Ortaya çıkan bu sonuç daha önce yapılan çalışmaların sonuçlarıyla benzerlik göstermektedir (Soriano, 2002; Namkung ve Jang, 2008; Pantelidis, 2010; Ha ve Jang, 2010; Zhang vd., 2010; Petzer ve Mackay, 2014; Doğan vd., 2016; Dalgıç vd., 2016). Hizmet kalitesinin ilk öneminin ilk sırada yer aldığı (Özbay ve Sarıca ,2020) çalışma ile farklılık göstermektedir. İkinci sırada yer alan servis kriteri (f:113), daha önceki çalışmalarla yine tutarlılık göstermektedir (Soriano, 2002; Kim vd., 2016). Yiyecek içecek işletmelerinin değerlendirilmesinde fiyat kriterinin (f:96) ise, önem taşıdığı ortaya çıkmıştır (Soriano, 2002; Pantelidis, 2010; Özaslan ve Uğur, 2014; Lei ve Law, 2015; Doğan vd. 2016; Kim vd., 2016). Şahin vd., 2018 çalışmasında fiyat en önemli kriter olarak karşımıza çıkmaktadır. Personel, temizlik ve atmosfer kriterlerinin de önemi çalışmada ortaya çıkmış ve daha önce yapılan çalışmalarda da vurgulanmıştır (Soriano, 2002; Pantelidis, 2010; Özaslan ve Uğur, 2014; Doğan vd., 2016; Kim vd., 2016; Dalgiç vd., 2016; Erdem ve Yay, 2017).

Bu çalışmanın sonuçları Şirince'de ki restoran yöneticilerinin müşteri şikayetlerinin nedenlerini anlamasını sağlayarak, şikayet konularındaki eksiklerini gidermelerine yardımcı olabilir. Personel konusunda daha hassas davranmaları gerekmekte, özellikle personelin müşteri ile etkili iletişim kurması sağlanmalıdır. Restoranlarda şikayetlerin ve önerilerin kolaylıkla yapılması için uygun bir sistem geliştirilmelidir. Personele de şikayetleri dinleme, anlama ve çözüm önerme konusunda eğitim desteği sağlanmalıdır. Müşteriler şikayetlerinin anlaşıldığını ve çözümlendiğini anladıklarında memnuniyet düzeyleri de artacaktır. Şirince'nin yabancı turist çeken bir destinasyon olmasından kaynaklı personelin yabancı dil bilgisinin de önemi üzerinde durulmalıdır. Özellikle haftasonu, bayram tatili gibi günlerde oluşacak kalabalık için destek personel temin etmeleri, böylelikle serviste oluşacak gecikmelerin de önünü geçmeleri sağlanacaktır. Çünkü en çok şikayet alınan konulardan biri servisin yavaş olmasıdır. Temizlik üzerinde hassasiyetle durulması gereken bir konudur. Özellikle masaların, çatal, bıçakların, bardakların temizliğine çok daha fazla önem verilmesi, tuvaletlerin gün içinde temizliğinin sık sık kontrol edilmesi gerekmektedir. Aynı zamanda sunulan yemeklerin lezzetli, hijyenik ve uygun sıcaklıklarda sunulması için gereken koşulları sağlamalıdır. Ayrıca fiyat da üzerinde de durulması gereken bir konudur. Fiyatın sunulan hizmetin üzerinde algılanması, verilen porsiyona göre çok yüksek olması şikayetlere yol açmaktadır. Fiyatlar farklı dillerde, mönü kartlarında belirtilmelidir ve tüm müşterilere aynı şekilde uygulanmalıdır. Restoran atmosferine yönelik olarak müşterileri yemek yerken rahatsız eden arı, kedi, köpek gibi hayvanlar için çözüm üretilerek, yemek yerken müşterilere rahatsızlık vermelerinin önüne geçilmelidir. Restoran içindeki gürültünün yemek yerken müşterileri rahatsız etmemesi sağlanmalı ve özellikle kış aylarında gelen müşteriler için restoran isıtmasının müşterilerin üşümeyeceği şekilde ayarlanması gerekmektedir. Çalışmada Şirince'de faaliyette bulunan restoranlardan hizmet alan müşterilerin Tripadvisor yorumları değerlendirilmiştir. Bundan sonra yapılacak çalışmalarda müşterilerle görüşmeler yaparak ya da nicel yöntemlerin kullanıldığı değerlendirmeler yapılabilir. Restoran yöneticilerinin görüşlere alınarak, yapılan şikayetlere nasıl çözüm buldukları konusu ayrı bir çalışmada değerlendirilebilir. Şirince gibi kırsal turizmin geliştiği farklı destinasyonlarda çalışma yapılarak karşılaştırma olanağı sağlanabilir.

\section{KAYNAKÇA}

Albayrak, A. (2013). Restoran İşletmelerinde Müşteri Şikayetleri ve Şikayete İlişkin Davranışlar. Paradoks Ekonomi, Sosyoloji ve Politika Dergisi, 9(2): 24-51. 
Arndt, J. (1967). Word of Mouth Advertising: A Review of the Literature, NY.: Advertising Research Foundation.

Anderson, E. W. (1998). Customer Satisfaction and Word of Mouth. Journal of Service Research, 1.1: $5-17$.

Buhalis, D., and Law, R. (2008). Progress in information technology and tourism management:

20 years on and 10 years after the Internetd the state of eTourism research. Tourism Management, 29(4) 609-623.

Cengiz, H. ve Başaran, S. (2016). Cep Telefonu Kullanıcılarının Tüketici Tecrübelerinin Değerlendirilmesi: Online Tüketici Yorumları Üzerine Netnografik Bir İnceleme. Tüketici ve Tüketim Araştırmaları Dergisi, 8(1): 73-92.

Cheung, C.M.K and Thadani, D. R., (2010). The Effectiveness of Electronic Word-of Mouth Communication: A Literature Analysis, 23rd Bled eConference, eTrust: Implications for the Individual, Enterprises and Society, 20th-23rd June, Bled, Slovenia

Cheung, C.M.K. and Lee, M. K. O. (2012). What Drives Consumers to Spread Electronic Word of Mouth in Online Consumer-Opinion Platforms. Decision Support Systems, 53, 218-225.

Dalgıç, A., Güler, O. ve Birdir, K. (2016). Tripadvisor.com'da Yer Alan Restoran Şikâyetlerinin Analizi: Mersin ve Hatay'da Yöresel Yiyecek Sunan Restoranlara Yönelik Bir Araştırma. Journal of Tourism and Gastronomy Studies, 4(Special Issue 1), 153-173.

Doğan S., Yücel G., ve M., Tanrısevdi A. (2016). Çevrimiçi Tüketici Yorumlarının İçerik Analizi Yoluyla İncelenmesi: Kuşadası'ndaki Yiyecek ve İçecek İşletmeleri Üzerinde Bir Araştırma, UHPAD (Uluslararası Hakemli Pazarlama ve Pazar Araştırmaları Dergisi, 9, 1-20.

Durmaz, A. ve Yüksel, M. (2017). The Effect of Ewom On Purchase Intention: Evidence from ECommerce Sites/ Ağızdan Ağıza İletişimin Satın Alma Niyetine Etkisi: E-Ticaret Siteleri Üzerine Bir Araştırma. Süleyman Demirel Üniversitesi İktisadi ve İdari Bilimler Fakültesi Dergisi, 22(1): 231239.

Erdem, Ö. ve Yay, Ö. (2017). Tripadvisor'daki müşteri şikâyetlerinin değerlendirilmesi: Antalya örneği. Journal of Tourism and Gastronomy Studies, 5 (4), 227-249.

Goodman, J., and Newman, S. (2003). Understand customer behavior and complaints, Quality Progress, 36 (1), 51-55.

Ha, J. and Jang, S. S. (2010). Effects of service quality and food quality: The moderating role of atmospherics in an ethnic restaurant segment, International Journal of Hospitality Management, 29(3), 520-529.

Hjalager, A. M. and Richards G. (2002). Tourism and Gastronomy, Routledge Advances in Tourism.

Ha, J. and Jang, S. (2013). Variety seeking in restaurant choice and its drivers. International Journal of Hospitality Management, 32, 155-168.

Jeong E., and Jang S. (2011). Restaurant experiences triggering positive electronic word-of-mouth (eWOM) motivations, International Journal of Hospitality Management, 30(2), 356-366.

Johns, N. and Kivela, J. (2001). Perceptions of the First Time Restaurant Customer, Food Service Technology, 1: 5-11.

Kalpaklığlu, N. U. and Toros, N. (2011). Viral Marketing Techniques Within Online Social Network, Journal of Yaşar University, 6.24: 4115-4132. 
Kim, W.G., Li, J.J., and Brymer, R.A. (2016). The Impact of Social Media Reviews on Restaurant Performance: The Moderating Role of Excellence Certificate. International Journal of Hospitality Management, 55, 41-51.

Kitapçı O. (2008). Restoran Hizmetlerinde Müşteri Şikayet Davranışları: Sivas İli'nde Bir Uygulama, Erciyes Üniversitesi İktisadi ve İdari Bilimler Fakültesi Dergisi, 31, 111-120.

Lewis, R. (1981), Restaurant Advertising: Appeals and Consumers' Intentions, Journal of Advertising Research, 21(5): 69-74.

Lee, S. C., Sunita B. S., and Kandampully, J. (2003). Technology, Service Quality and Customer Loyalty in Hotels: Australian Managerial Perspectives. Managing Service Quality, 13(5): 423-432.

Lee, J., Park, D. H., and Han, I. (2008). The effect of negative online consumer reviews on product attitude: An information processing view. Electronic Commerce Research and Applications, 7(3), 340353.

Lee, S. H., Noh, S. E., and Kim, H. W. (2013). A mixed methods approach to electronic word ofmouth in the open-market context. International Journal of Information Management, 33(4), 687-696.

Lewis, R. C. (1983). When Guests Complain. Cornell Hotel and Restaurant, Administration Quarterly, 24, 23-32

Liu, Y. and Jang, S. S. (2009). Perceptions of Chinese restaurants in the U.S.: What affects customer satisfaction and behavioral intentions?. International Journal of Hospitality Management, 28, 338-348.

Li, H., Meng, F., Jeong, M. and Zhang, Z. (2020). To follow others or be yourself? Social influence in online restaurant reviews, International Journal of Contemporary Hospitality Management, 32, 1067-1087. https://doi.org/10.1108/IJCHM-03-2019-0263.

Lei, S., and Law, R., (2015). Content Analysis of Tripadvisor Reviews on Restaurants: A Case Study of Macau, Journal of Tourism, 6(1):17-28.

Moquadamsalimi T. (2019). Elektronik Ağızdan Ağıza Pazarlamanın Tüketici Satın Alma Kararına Etkisi: Bir Uygulama, Gazi Üniversitesi, Sosyal Bilimler Enstitüsü, İşletme Anabilim Dalı, Yüksek Lisans Tezi.

Namkung, Y. and Jang, S. S. (2008). Are highly satisfied restaurant customers really different? A quality perception perspective, International Journal of Contemporary Hospitality Management, 20 (2), 142-155.

O'Connor, P. (2008). User-generated content and travel: a case study on Tripadvisor.com. Information and Communication Technologies in Tourism. Wien, Springer, pp: 47-58.

Özbay, G. ve Sarıca, V. (2020). Yiyecek İçecek İşletmelerinde Şikâyet Yönetimi Uygulamaları: Sakarya Örneği, Türk Turizm Araştırmaları Dergisi, 4(2): 856-880.

Özaslan Y., ve Uygur S. (2014). Negatif Ağızdan Ağıza İletişim (Wom) ve Elektronik Ağızdan Ağıza İletişim (E-Wom): Yiyecek-İçecek İşletmelerine Yönelik Bir Araştırma, Atatürk Üniversitesi İktisadi ve İdari Bilimler Dergisi, 28, 69-88.

Pantelidis, I.S. (2010). Electronic Meal Experience: A Content Analysis of Online Restaurant Comments, Cornell Hospitality Quarterly, 51(4):483-491

Petzer D., and Mackay N. (2014). Dining atmospherics and food and service quality as predictors of customer satisfaction at sit-down restaurants, African Journal of Hospitality, Tourism and Leisure, $3,1-14$ 
Sijoria, Ch., Mukherjee, S. and Datta, B. (2018). Impact of the antecedents of eWOM on CBBE. Marketing Planning E Intelligence, 36(5), 528-543.

Soriano, D. R. (2002). Customers' expectations factors in restaurants: The situation in Spain, International Journal of Quality \& Reliability Management, 19(8/9), 1055-1067.

Şahin, S., Girgin, G. K., Kazoğlu, İ. H. ve Coşkun, G. N. (2018). Gastronomi turistlerinin e-şikâyet davranışları üzerine bir araştırma: Alaçatı örneği. Journal of Tourism and Gastronomy Studies, 6 (1), $68-82$.

Tripadvisor. (2020). https://www.tripadvisor.mediaroom.com/tr-about-us (Erişim Tarihi 10.06.2020)

Tiago, T., Amaral, F., and Tiago F., (2015). The Good, The Bad and The Ugly: Food Quality in UGC, Procedia Social and Behavioral Sciences, 175, 162-169.

Unur, K., Çakıcl, A.C. ve Taştan, H. (2010). Seyahat Acentelerinde Uygulanmakta Olan Müşteri Şikâyet Çözüm Türleri Üzerine Bir Araştırma. Balıkesir Üniversitesi Sosyal Bilimler Enstitüsü Dergisi, 13(24), 241-253.

Zhang, Z., Ye, Q., Law, R. and Li, Y. (2010). The Impact of E-Word-of-Mouth on the Online Popularity of Restaurants: A Comparison of Consumer Reviews and Editor Reviews. International Journal of Hospitality Management, 29, 694-700. 